\title{
Effect of Injectable Vitamin and Trace Element Administrations During Transition Period on Fertility in Brown Swiss Dairy Cows
}

\author{
Murat Onur YAZLIK ${ }^{*}$, Mehmet Rıfat VURAL², Şükrü KÜPLÜLÜ3 ${ }^{3}$ Mert PEKCAN ${ }^{4}$ \\ ${ }^{1}$ Ankara University, Faculty of Veterinary Medicine Department of Obstetrics and Gynecology, 06110 Ankara, Turkey \\ ${ }^{2}$ Ankara University, Faculty of Veterinary Medicine Department of Obstetrics and Gynecology, 06110 Ankara, Turkey \\ ${ }^{3}$ Ankara University, Faculty of Veterinary Medicine Department of Obstetrics and Gynecology, 06110 Ankara, Turkey \\ ${ }^{4}$ Ankara University, Faculty of Veterinary Medicine Department of Biochemistry, 06110 Ankara, Turkey
}

\begin{abstract}
This study examined the effects of injectable vitamin and trace element combination during the transition period on clinical-biochemical parameters and reproductive performance in Brown Swiss dairy cows. Sixty multiparous cows were randomly allocated two groups as trace element-vitamin treated $(n=30)$ and control $(n=30)$. Animals received four injections at the beginning of the dry period, 21 days before parturition, the day of parturition, and postpartum $30 \pm 5$ days. Energy, protein, hepatic metabolism markers, blood mineral levels concentrations were measured at $-7 \pm 4$ days antepartum, $3 \pm 2$ days, and $30 \pm 5$ days postpartum. Genital tract examinations were performed at $30 \pm 5$ day postpartum. Treated cows showed lower glucose, total protein, urea, and greater NEFA concentration $-7 \pm 4$ days relative to calving. Effect of vitamin and trace element on serum calcium and phosphorus levels were significant. The total pregnancy rate was $95.8 \%$ and $59.09 \%$, in treatment and control groups respectively at 150 days postpartum $(\mathrm{P}<0.05)$. In conclusion, trace element and vitamin supplementation increased pregnancy rate significantly and treatment positively affected energy, ion metabolism, and hepatic function.
\end{abstract}

Keywords: Vitamin and trace element, transition period, fertility

\begin{abstract}
$* * *$
İsviçre Esmeri ineklerde geçiş döneminde vitamin, iz element uygulamalarının fertiliteye etkisinin araştırılması
\end{abstract}

ÖZ

Bu çalışmada geçiş dönemi boyunca vitamin ve iz element enjeksiyonlarının, klinik-biyokimyasal parametreler, periparturent dönem sorunları ile fertilite parametrelerinin üzerine etkisinin araştırılması amaçlandı. Altmış inek, iz element ve vitamin enjeksiyonu yapilanlar $(n=30)$ ve kontrol grubu $(n=30)$ olarak rastgele iki gruba ayrild. Vitamin ve iz element enjeksiyonları kuru döneme girişte, doğumdan 21 gün önce, doğumun gerçekleştiği gün ve doğumu

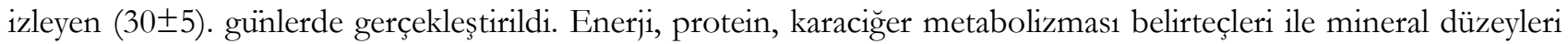
doğum öncesi $7 \pm 4$. gün, doğum sonras $13 \pm 2$. gün ve $30 \pm 5$. günlerde ölçüldü. Genital organ muayeneleri doğum sonras $30 \pm 5$. günde gerçekleştirildi. Uygulama grubundaki inekler kontrol grubundakilere kıyasla doğum öncesi $7 \pm 4$ günde daha düşük glikoz, toplam protein, üre ve daha yüksek NEFA konsantrasyonu gösterdi. Vitamin ve iz element uygulamasının serum kalsiyum ve fosfor düzeylerine etkisi önemli düzeydeydi. Doğum sonrası 150. günde toplam gebelik oranı uygulama ve kontrol gruplarında sırasıyla \% 95.8 ve \% 59.09 olarak saptandı $(\mathrm{P}<0.05)$. Sonuç olarak, iz element ve vitamin uygulanan ineklerde toplam gebelik oranının belirgin olarak arttığ1 ve uygulamaların enerji, iyon metabolizması ve karaciğer fonksiyonlarını olumlu etkilediği belirlendi.

Anahtar Kelimeler: Vitamin ve iz element, geçiş dönemi, fertilite

To cite this article: Yazhle M.O. Vural M.R. Küplïlü Ş. Pekcan M. Effect of Injectable Vitamin and Trace Element Administrations During Transition Period on Fertility in Brown Swiss Dairy Cows. Kocatepe Vet J. (2021):14(1):113-122

Submission: 09.01.2021 Accepted: 26.02.2021 Published Online: 26.02.2021

ORCID ID; MOY: 0000-0002-0039-5597 MRV: 0000-0001-7252-7977 ŞK: 0000-0001-7488-9736 MP: 0000-0003-3084-125X

*Corresponding author e-mail: yazlik@ankara.edu.tr 


\section{INTRODUCTION}

The transition period is defined as three weeks before and after parturition and the most challenging dairy cows' lactation duration. Metabolic, hormonal and immunologic alterations are the characteristic of this period (Bell 1995). During the transition period animals are susceptible to metabolic and infectious disorders due to increased demand for energy and minerals (Drackley et al. 2005, Sordillo and Aitken 2009). As a response to energy deficiency, dairy cows mobilize their body reserves (Drackley et al. 2001). Consequently, non-esterified fatty acids (NEFAs) and beta-hydroxybutyric acid (BHB) concentrations increase in blood during the transition period. Subsequently, dry matter intake and calcium ion concentration decrease which increased cortisol concentration. The high concentration of fatty acids, ketone bodies, cortisol and decreased calcium levels impairs immune response (Scalia et al. 2006, Contreras et al. 2010). Increased metabolic demands, parturition and metabolic stress alter the oxidant and antioxidant balance leading to oxidative stress (Sordillo and Aitken 2009). Oxidative stress and negative energy balance, lead to trace element and vitamin deficiencies (Hayırlı et al. 2002, Machado et al. 2013). An injectable form of trace elements and vitamins provides an alternative way of delivering extra trace elements and vitamins during the transition period. And leads an increase in tissues within several hours or days (Pogge et al. 2012). Trace elements or vitamin supplementation during the transition period minimize the stillbirth risk, retained placenta, uterus infections and mastitis. Furthermore, it increases fertility (Politis, 2012, Machado et al. 2013, Pontes et al. 2015). At the same time, they had no adverse effect on hematologic and immune parameters (Bicalho et al. 2014, Schäfers et al. 2018).

Due to the decrease of dry matter intake, an increase of growing fetus requirement and beginning of colostrogenesis and lactogenesis process resulted with trace element and vitamin insufficiency. The farming systems changed over the last few decades; thus intensive cattle breeding resulted in nutrient losses of feed due to storage problems (Tilman et al. 2002). On the other hand, trace elements associated with fiber fractions in the feedstuff and/or binding of undigested fiber to the trace minerals decreases the bioavailability. Due to immune response and oxidative status of cows altered during the transition period, the incidence of puerperal disorders increases (Sundrum 2015). The process of follicular development from the primordial pool takes 4 to 5 months to reach the ovulation phase in dairy cows (Webb et al. 2003); thus follicular growth starts from the late stage of gestation, the increased demand of trace element and vitamins might mitigate the follicular growth or oocyte quality. It was aimed to investigate the effects of vitamin, trace element, and mineral supplementation during the dry and transition period on clinical-biochemical parameters, periparturient problems, and fertility.

\section{MATERIALS and METHODS}

All experiments on animals were carried out according to the standards approved by the Animal Welfare and Research Ethics Committee at Ankara University (2015-12-139).

\section{Animals and Housing}

This study was conducted on a farm incorporated in the Directorate General of Agricultural Enterprises in Turkey. Cows were monitored from the beginning of dry period (-60 d) until five months postpartum (150 d) for the determination of any puerperal disorders and calving as well as postpartum diseases. Serological controls (brucellosis, tuberculosis, neosporosis) and vaccinations (Bovine Herpesvirus-1, Bovine viral diarrhea virus, coronavirus, rotavirus) were performed regularly. The barns were naturally ventilated and artificially lighting. According to NRC recommendations, cows were fed total mixed rations (TMRs) ad libitum $(09.00,16.00$ and $00.00 \mathrm{~h}$ ) to meet their nutrient requirements (NRC 2001). The composition of the TMR was shown in Table 1. TMR was prepared daily by vertical mixer feeder and offered three times with diet portions equally split between three feedings.

\section{Experimental Design and Treatments}

A total of 60 pregnant multiparous Brown Swiss dairy cows between 2 to 4 lactations were enrolled in the study. Animals were randomly divided into two groups as treatment $(n=30)$ and control $(n=30)$ at the beginning of the dry period. Cows were randomized using the random number function in Microsoft Excel (Redmond, WA, USA) and imported into the farm's Dairy Plan (GEA ${ }^{\circledR}$, Germany). Cows that assigned to treatment groups received four injections of trace element (Activate, Alke ${ }^{\circledR}$, Turkey, $8 \mathrm{ml}$ ) and vitamin (Ademin ${ }^{\circledR}$, Ceva, France, $10 \mathrm{ml}$ ) combination at 230 and $260 \pm 5$ days of pregnancy, around parturition and $30 \pm 5$ days in milk (DIM). Each trace mineral injection contains $2.5 \mathrm{mg} \mathrm{Cu}, 1.25 \mathrm{mg} \mathrm{Se}, 5 \mathrm{mg} \mathrm{Mn}$ and $5 \mathrm{mg}$ Zn per $\mathrm{ml}$. Each vitamin injection contains $500000 \mathrm{IU}$ vitamin A, $75000 \mathrm{IU}$ vitamin D3 and $50 \mathrm{mg}$ vitamin $\mathrm{E}$ per $\mathrm{ml}$. The control groups received $0.9 \%$ isotonic sodium chloride $(\mathrm{NaCl})$ with the same volume. For the first three days following the parturition the treatment and control animals received calcium and phosphorus solutions parenterally. 
Table 1. Integrant of diets fed during far-off (-60 to $-31 \mathrm{~d}$ relative to expected calving), close-up ( $-30 \mathrm{~d}$ to calving), and early lactation.

\begin{tabular}{cccc}
\hline Component & Far-off & Close-up & Early Lactation \\
\hline Ingredient. \% of DM & & & \\
Vetch hay & 11.58 & - & - \\
Alfalfa silage & - & - & 9.67 \\
Alfalfa hay & 7.89 & 6.97 & 10.29 \\
Corn silage & 52.6 & 43.51 & 44.16 \\
Wheat straw & 10.52 & 22.25 & - \\
Soybean meal. 48\% CP & - & - & 1.61 \\
Concentrated feed & 15.78 & 20.94 & 30.31 \\
Limestone & 0.82 & 2.25 & 1.57 \\
Salt & 0.30 & - & 0.26 \\
Ammonium chloride & - & 1.15 & - \\
Dicalcium phosphate & 0.14 & 0.3 & 0.44 \\
Magnesium oxide & - & 0.12 & 0.44 \\
Magnesium sulphate & 0.16 & 1.35 & 0.25 \\
Sodium bicarbonate & - & - & 0.7 \\
Calcium sulphate & - & - & 0.1 \\
Mineral-vitamin mix ${ }^{1}$ & 0.21 & 0.17 & 0.2 \\
\hline
\end{tabular}

${ }^{1}$ Contained a minimum of $4.3 \% \mathrm{Mg}, 8 \% \mathrm{~S}, 6.1 \% \mathrm{~K}, 2.0 \% \mathrm{Fe}, 3.0 \% \mathrm{Zn}, 3.0 \% \mathrm{Mn}, 5000 \mathrm{mg} / \mathrm{kg} \mathrm{Cu}, 250 \mathrm{mg} / \mathrm{kg}$ of I, $40 \mathrm{mg} / \mathrm{kg}$ of Co, $150 \mathrm{mg} / \mathrm{kg}$ Se, $2200 \mathrm{kIU} / \mathrm{kg}$ of vitamin A, 660kIU/ $\mathrm{kg}$ of vitamin D3, and $7700 \mathrm{IU} / \mathrm{kg}$ of vitamin E.

\section{Blood Sampling and Metabolite, Ion Analyses}

Blood samples were collected before the morning feeding on the coccygeal artery or vein into Vacutainer tubes without anticoagulant (Hema\&Tube $\left.{ }^{\circledR}\right)$ using 20gauge $\times 2.54 \mathrm{~cm}$ Vacutainer needle (Vacutainer, Becton, Dickenson and Company) at $7 \pm 4$ days before the expected calving date, $3 \pm 2$ and $30 \pm 5$ days postpartum. Samples were clotted and then placed on ice until processing. Blood samples delivered to the farm laboratory under the cold chain then were centrifuged at $1300 \mathrm{xg},+4^{\circ} \mathrm{C}$ for 10 minutes in the first 15-60 minutes after collection. The serum was separated and collected into $1,5 \mathrm{ml}$ tubes containing information such as ear number, administration group, blood collection date, and stored in a freezer at $-20^{\circ} \mathrm{C}$ in the farm laboratory (Little et al. 2017). At the end of the study the serum samples placed on the ice molds in the biological sample carrying bag were delivered to the Biochemistry Laboratory of the Faculty of Veterinary Medicine, Ankara University. Serum samples were analyzed for the determination the concentration of NEFA, BHB, glutamate dehydrogenase $(\mathrm{GLDH})$, glucose, albumin, total protein, urea, creatine kinase (CK), alanine aminotransferase (ALT), alkaline phosphatase (ALP), aspartate aminotransferase (AST), gamma glutamyl transferase (GGT), lactate dehydrogenase (LDH), cholesterol, triglyceride, total bilirubin (TBIL), direct bilirubin (DBIL), calcium (Ca), phosphorus (P), magnesium $(\mathrm{Mg})$, potassium
$(\mathrm{K})$, sodium $(\mathrm{Na})$, chlorine $(\mathrm{Cl})$ in blood serum (Hoedemaker et al. 2004) by using commercial kits

following manufacturer instructions with auto analyzer (ERBA XL 600®) equipped with spectrophotometric and ion-selective electrode (ISE) in Ankara University Faculty of Veterinary Medicine Diagnostic Laboratory. All analyses were calibrated using ERBA XL Multical ${ }^{\circledR}$ and calibration verified using two control serum (ERBA Norm ${ }^{\circledR}$ and ERBA PATH®). GLDH levels of serum samples were determined by a 96-well microplate reader device (Sunrise ${ }^{\circledR}$, Tecan, Switzerland) with a Magellan TM data analysis software with a spectral wave range of $400-750 \mathrm{~nm}$.

\section{Reference Blood Values}

The physiological upper limit for NEFA $0.3 \mathrm{mEq} / \mathrm{L}$ in the prepartum period and $0.7 \mathrm{mEq} / \mathrm{L}$ postpartum were proposed by McArt et al. (2012). The reference concentration level for BHB was below $1200 \mathrm{mmol} / \mathrm{L}$ postpartum (Ospina et al. 2010). According to Goff (2014), blood serum total Ca concentration $8.5 \mathrm{mg} / \mathrm{dl}$ and below were defined as subclinical hypocalcaemia. The physiological limit of phosphorus concentration was accepted as $4-8 \mathrm{mg} / \mathrm{dl}$ (NRC, 2001).

\section{Body Condition Score}

The animals' body condition scores were determined on the start of the dry period and days of blood collection as previously described by Ferguson et al. (1994). 
The normal-stillbirth and the sex of calf and dystocia score were recorded by using the system as previously described by Heins et al. (2006). During the postpartum period, body temperature, appetite and rumen fullness were examined and recorded twice a day for five days.

\section{Postpartum vagina, uterus and ovary examination} Postpartum genital tract examination performed on $30 \pm 5 \mathrm{~d}$ postpartum. The vaginal examination was performed by hand for the purpose of evaluating the vaginal discharge scoring. Before the examination, the vulva was cleaned by a paper towel. A gloved and lubricated hand inserted to the vagina. Discharges in the anterior vagina accumulated (Little et al. 2017). Vaginal discharges scored by using the system Williams et al. (2005). Animals with mucopurulent, purulent or malodorous discharge at the time of examination were diagnosed with clinical endometritis. The transrectal ultrasonography examination of the ovaries was performed using a linear probe with a frequency of 6.5$9 \mathrm{MHz}$ (SIUI ${ }^{\circledR}$, CTS 800, China). The presence of follicles with a diameter of less than $20 \mathrm{~mm}$ and greater than $9 \mathrm{~mm}$ on the ovaries were detected and the measurements were recorded (Tanaka et al. 2008). In the absence of corpus luteum in the ultrasonography examination of ovaries, the structures with dimensions of $2.5 \mathrm{~cm}$ or more were considered ovarian cyst (Silvia et al. 2005). The presence of corpus luteum was also investigated. Animals that had a corpus luteum recorded as cyclic. Animals with corpus luteum were treated with PGF2 $\alpha$ (Enzoprost-T®, CEVA, France) containing $25 \mathrm{mg}$ of dinoprost. animals that did not consist a corpus luteum treated with $\mathrm{GnRH}$ (Ovarelin ${ }^{\circledR}$, CEVA, France) containing $100 \mathrm{mcg}$ of Gonadorelin diacetate tetrahydrate. Animals clinical endometritis were treated with the unique intrauterine treatment protocol as determined by the General Directorate of Agricultural Enterprises and other parenteral treatment protocols.

\section{Fertility Parameters}

The oestrus symptoms were detected visually by experienced farm personnel from the 50th day of the postpartum. All animals were examined before the inseminations. Each cow was inseminated until 150 days postpartum. Transrectal ultrasonography examinations were performed to determine whether the pregnant or non-pregnant animals at $30 \pm 2$ days post insemination. After the inseminations, pregnancy rates, total pregnancy rates, the number of insemination, and calving to pregnancy interval were evaluated (Hoedemaker et al. 2009).

\section{Statistical Analysis}

Before performing the statistical analysis, data were examined with the Shapiro-Wilk test for normality and
Levene test for homogeneity of variances as parametric test assumptions. Descriptive statistics for each variable were calculated and presented as "mean \pm standard error of the mean". Chi-square test was used to determine the difference between treatment and control groups following measures, presence of corpus luteum, pregnancy rates, and uterus infection. The difference between calving to first AI, calving to conception interval, number of inseminations and lactations parameters, Mann- Whitney U test was performed.

The effect of group, day of sampling and their interaction on NEFA, BHB, GLDH, glucose, albumin, total protein, urea, CK, ALT, ALP, AST, GGT, LDH, cholesterol, triglyceride, TBIL, DBIL, Ca, P, Mg, K, $\mathrm{Na}$, and $\mathrm{Cl}$ were analyzed using MIXED procedure of SPSS (V22.0; SPSS Inc. Chicago, IL, USA), the following model with repeated measures

$Y \_i j k=\mu+G \_i+Z \_j+(\llbracket G \times Z) \rrbracket \_i j+e \_i j k$

Where $Y_{-}$ijk was the dependent variable, $\mu$ was the overall mean, $G \_i$ was the effect of the group ( $i=$ Treatment and control), $Z \_j$ was the effect of day of sampling $(j=-7 \pm 4,3 \pm 2$, and $30 \pm 5 d),(\llbracket G \times Z)$ $\rrbracket$ _ij represented interaction between group $i$ and day of sampling $j$, and e_ijk was the residual error.

Animals within the group were assessed as a random effect, while group, period, or day of sampling and their interaction were assessed as a fixed effect. $\mathrm{P}<0.05$ was considered significant in all analyses. When a significant difference was revealed, any significant terms were compared by simple effect analysis with Bonferroni adjustment.

\section{RESULTS}

Six animals from the treatment and eight animals from the control group were excluded from the study as per management policies. There was no significant difference between mean lactation numbers among groups. Trace element and vitamin supplementation did not affect BCS in cows. The BCS was influenced by time only, showing a drop toward $30 \pm 5$ DIM.

\section{Postpartum Period and Fertility Parameters}

Body temperature and time of rumination in 5 days postpartum were similar in both groups. The number of cases for retained placenta were not affected by treatment. Treatment did not affect on the incidence of clinical endometritis. The $66.6 \%$ of cows were considered cyclic at $30 \pm 5$ DIM. There was no effect of treatment on cyclicity $(\mathrm{P}>0.05)$. Also, treated cows showed similar calving to conception interval, calving to first AI interval compared to control cows. Additionally, the number of inseminations were similar among groups. The pregnancy rate at first and third service did not differ between treatment and control cows. However, the odds of second insemination and total pregnancy were greater in the treatment group 
than the control group at 150 days postpartum $(\mathrm{P}<0.05$, Table 2$)$.

\section{Energy and Protein Metabolism Markers}

The main treatment and interactive effects on blood energy and protein biomarkers are presented in Table 3. Supplementation with trace elements and vitamins did not affect the serum concentration of BHB $(\mathrm{P}>0.05)$. NEFA, glucose, total protein, albumin, and urea concentration changed over time. Also, these parameters affected by the interaction between treatment and time. The glucose concentration showed most significant decrease around parturition in control cows $(\mathrm{P}<0.05)$. NEFA concentration was greater however, serum glucose, total protein, albumin and urea concentration were lower in the treatment group at prepartum period $(\mathrm{P}<0.05)$. Treated cows had increased urea levels after parturition compared to the levels at pre-calving sampling levels and showed similar urea concentrations during the postpartum period. The total proteins marginally decreased in control cows in the early postpartum period $(\mathrm{P}<0.05)$. Although treated cows showed greater NEFA, glucose and urea concentrations, they did not reach the pathological threshold levels after parturition (Table $3)$.

\section{Enzyme and Liver Function Markers}

GLDH, AST, LDH, cholesterol, BIT and BID concentration changed over time significantly $(\mathrm{P}<0.05)$. There was only an interaction noted between time and treatment for ALT and cholesterol levels. Prepartum decreased ALT concentration was shown in the treatment group $(\mathrm{P}<0.05)$. Cholesterol concentration decreased in the treatment group at $30 \pm 5$ days postpartum (Table 3 ).

\section{Mineral Concentrations}

All mineral panel parameters changed over time, but, there was only interaction between treatment and time for calcium and phosphorus concentration. Chlorine, sodium, potassium and magnesium concentrations were similar among groups. Prepartum calcium and phosphorus concentration were lower in the treatment group $(\mathrm{P}<0.05)$. Mean calcium concentration was in subclinical hypocalcaemia levels in control cows after parturition (Table 3). Treatment with trace elements and vitamins during the transition period did not affect pre-postpartum $\mathrm{Mg}, \mathrm{Na}, \mathrm{K}, \mathrm{Cl}$ levels.

Table 2. Findings of genital tract examination on $30 \pm 5$ days postpartum and fertility parameters.

\begin{tabular}{|c|c|c|c|}
\hline \multirow[t]{2}{*}{ Items } & \multicolumn{2}{|c|}{ Animals } & \multirow[t]{2}{*}{$\mathbf{P}$} \\
\hline & $\begin{array}{l}\text { Treatment } \\
(n=24)\end{array}$ & $\begin{array}{c}\text { Control } \\
(n=22)\end{array}$ & \\
\hline Clinical Endometritis & $10 / 24$ & $6 / 22$ & 0.210 \\
\hline Presence of $C L$ & $16 / 24$ & $10 / 22$ & 0.092 \\
\hline Ovarian Cyst & $1 / 24$ & $1 / 22$ & - \\
\hline $\begin{array}{l}\text { Number of animals that } \\
\text { have follicle within } 12-20 \\
\text { mm in the absence of CL }\end{array}$ & $4 / 24$ & $7 / 22$ & - \\
\hline $\begin{array}{l}\text { Calving to first AI interval } \\
\text { (days) }(\overline{\times} \pm \mathrm{SEM})\end{array}$ & $91.84 \pm 9.65$ & $105.48 \pm 7.40$ & 0.300 \\
\hline $\begin{array}{l}\text { Calving to conception } \\
\text { interval (days) }(\overline{\times} \pm S E M)\end{array}$ & $121.69 \pm 13.28$ & $111.27 \pm 11.7$ & 0.527 \\
\hline $\begin{array}{l}\text { Number of inseminations } \\
(\overline{\times} \pm \text { SEM })\end{array}$ & $1.65 \pm 0.15$ & $1.87 \pm 0.19$ & 0.564 \\
\hline $\begin{array}{l}\text { Pregnancy rate after } 1 \text { st } \mathrm{AI} \\
(\%)\end{array}$ & 41.18 & 28 & 0.374 \\
\hline $\begin{array}{l}\text { Pregnancy rate after } 2 \mathrm{nd} \mathrm{AI} \\
(\%)\end{array}$ & $80^{\text {B.a }}$ & $21.43^{\mathrm{A}}$ & 0.005 \\
\hline $\begin{array}{l}\text { Pregnancy rate after } 3 \mathrm{rd} \mathrm{AI} \\
\text { (\%) }\end{array}$ & 100 & 83.33 & 0.659 \\
\hline Total pregnancy rate (\%) & $95.8^{\text {B.a }}$ & $59.09^{\mathrm{A}}$ & 0.003 \\
\hline
\end{tabular}

Means within a row (a-c) and column (A-B) with differ superscript letters differ significantly $(\mathrm{P}<0.05)$.

Treatment: Cows supplemented with trace element and Vitamin Combination

Control: Control group

$(\times)$ : Average

SEM: Standart Error Mean

$\mathrm{CL}=$ Corpus Luteum

Table 3. The effect of trace element and vitamin treatment on blood serum metabolites during the pre-. post-partum period $\left(\times^{\llcorner} \pm\right.$SEM $)$. 


\begin{tabular}{|c|c|c|c|c|c|c|}
\hline & \multirow{2}{*}{$\begin{array}{c}\text { Prepartum } \\
-7 \pm 4 d\end{array}$} & \multicolumn{2}{|c|}{ Postpartum } & \multicolumn{3}{|c|}{$\mathbf{P}$} \\
\hline & & $3 \pm 2 d$ & $30 \pm 5 \mathrm{~d}$ & Treatment & Time & Treatment*Time \\
\hline \multicolumn{7}{|c|}{$\begin{array}{c}\text { Energy and Protein Metabolism } \\
\text { Markers }\end{array}$} \\
\hline \multicolumn{7}{|c|}{ NEFA (mEq/L) } \\
\hline Treatment & $0.48 \pm 0.11^{\mathrm{ab} . \mathrm{A}}$ & $\begin{array}{c}0.58 \pm 0.05^{\mathrm{a}} \\
\mathrm{A}\end{array}$ & $0.30 \pm 0.03^{\mathrm{b}}$ & 0.000 & 0.004 & 0.007 \\
\hline Control & $0.11 \pm 0.003^{\text {b. B }}$ & $\begin{array}{c}0.32 \pm 0.04^{\mathrm{a}} \\
\mathrm{B}\end{array}$ & $\begin{array}{l}0.27 \pm \\
0.03^{\mathrm{ab}}\end{array}$ & & & \\
\hline \multicolumn{7}{|l|}{ Urea (mg/dl) } \\
\hline $\begin{array}{l}\text { Treatment } \\
\text { Control }\end{array}$ & $\begin{array}{l}24.99 \pm 1.30^{\mathrm{b} . \mathrm{B}} \\
29.26 \pm 1.34^{\mathrm{A}}\end{array}$ & $\begin{array}{l}37.88 \pm 3.34^{\mathrm{a} . \mathrm{A}} \\
29.18 \pm 2.66^{\mathrm{B}}\end{array}$ & $\begin{array}{c}32.60 \pm 3.26^{\mathrm{a}} \\
31.37 \pm 1.79\end{array}$ & 0.476 & 0.008 & 0.010 \\
\hline \multicolumn{7}{|l|}{$\begin{array}{l}\text { Glucose } \\
(\mathrm{mg} / \mathrm{dl})\end{array}$} \\
\hline $\begin{array}{l}\text { Treatment } \\
\text { Control }\end{array}$ & $\begin{array}{c}60.17 \pm 1.65^{\text {B }} \\
67.69 \pm 1.71^{\text {a. A }}\end{array}$ & $\begin{array}{c}61.96 \pm 3.20^{\mathrm{A}} \\
52.44 \pm 2.78^{\mathrm{b} . \mathrm{B}}\end{array}$ & $\begin{array}{l}57.13 \pm 2.29 \\
57.44 \pm 2.25^{\mathrm{b}}\end{array}$ & 0.740 & 0.014 & 0.005 \\
\hline \multicolumn{7}{|l|}{$\begin{array}{l}\text { T. Protein } \\
(\mathrm{g} / \mathrm{dl})\end{array}$} \\
\hline $\begin{array}{l}\text { Treatment } \\
\text { Control }\end{array}$ & $\begin{array}{l}6.38 \pm 0.18^{\text {b. B }} \\
7.61 \pm 0.14^{\text {a. A }}\end{array}$ & $\begin{array}{c}6.68 \pm 0.17^{\mathrm{ab}} \\
6.27 \pm 0.29^{\mathrm{b}}\end{array}$ & $\begin{array}{l}7.31 \pm 0.26^{\mathrm{a}} \\
7.48 \pm 0.25^{\mathrm{a}}\end{array}$ & 0.121 & 0.000 & 0.001 \\
\hline \multicolumn{7}{|c|}{ Albumin (g/dl) } \\
\hline Treatment & $3.19 \pm 0.06^{\mathrm{b}}$ & $3.47 \pm 0.06^{\mathrm{a}}$ & $\begin{array}{l}2.95 \pm \\
0.08^{\mathrm{b} . \mathrm{B}}\end{array}$ & 0.369 & 0.003 & 0.003 \\
\hline Control & $3.35 \pm 0.07$ & $3.24 \pm 0.1$ & $\begin{array}{c}3.23 \pm \\
0.09^{\mathrm{A}}\end{array}$ & & & \\
\hline \multicolumn{7}{|c|}{$\begin{array}{l}\text { Enzymes and Hepatic } \\
\text { Function Markers }\end{array}$} \\
\hline \multicolumn{7}{|c|}{ ALT (IU/L) } \\
\hline $\begin{array}{l}\text { Treatment } \\
\text { Control }\end{array}$ & $\begin{array}{c}19.70 \pm 1.04^{\mathrm{B}} \\
27.08 \pm 2.23^{\mathrm{a} . \mathrm{A}}\end{array}$ & $\begin{array}{c}20.53 \pm 1.23 \\
20.63 \pm 1.35^{\mathrm{b}}\end{array}$ & $\begin{array}{l}21.90 \pm 1.67 \\
21.40 \pm 1.06^{\mathrm{b}}\end{array}$ & 0.139 & 0.077 & 0.003 \\
\hline \multicolumn{7}{|l|}{$\begin{array}{l}\text { Cholesterol } \\
(\mathrm{mg} / \mathrm{dl})\end{array}$} \\
\hline Treatment & $84.17 \pm 4.23^{b}$ & $76.38 \pm 4.93^{b}$ & $\underset{B}{104.54 \pm 6.32^{\mathrm{a}}}$ & 0.267 & 0.000 & 0.000 \\
\hline Control & $82.85 \pm 3.38^{\mathrm{b}}$ & $64.85 \pm 4.86^{\mathrm{c}}$ & $\underset{A}{136.35 \pm 7.43^{\mathrm{a}}}$ & & & \\
\hline \multicolumn{7}{|l|}{ Minerals } \\
\hline $\begin{array}{l}\text { Treatment } \\
\text { Control }\end{array}$ & $\begin{array}{l}8.20 \pm 0.21^{\text {b. B }} \\
9.93 \pm 0.09^{\text {a. A }}\end{array}$ & $\begin{array}{l}8.54 \pm 0.21^{\mathrm{ab}} \\
8.07 \pm 0.33^{\mathrm{c}}\end{array}$ & $\begin{array}{l}9.16 \pm 0.13^{\mathrm{a}} \\
8.92 \pm 0.20^{\mathrm{b}}\end{array}$ & 0.073 & 0.000 & 0.000 \\
\hline $\mathrm{P}(\mathrm{mg} / \mathrm{dl})$ & & & & & & \\
\hline $\begin{array}{l}\text { Treatment } \\
\text { Control }\end{array}$ & $\begin{array}{c}6.08 \pm 0.20^{\mathrm{B}} \\
7.12 \pm 0.21^{\text {a. }} \mathrm{A}\end{array}$ & $\begin{array}{c}5.88 \pm 0.27^{\mathrm{A}} \\
4.50 \pm 0.22^{\text {b. B }}\end{array}$ & $\begin{array}{l}6.70 \pm 0.49 \\
6.67 \pm 0.60^{\mathrm{a}}\end{array}$ & 0.714 & 0.000 & 0.005 \\
\hline
\end{tabular}

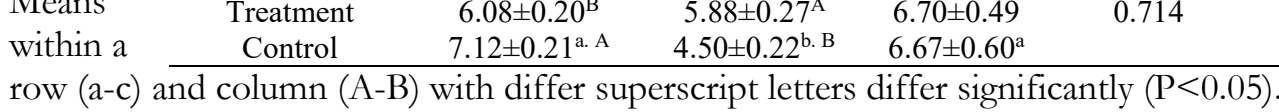

Treatment: Cows supplemented with trace element and Vitamin Combination

Control: Control group

$\left({ }^{\top}\right)$ : Average

SEM: Standart Error Mean

\section{DISCUSSION}

This study evaluated the effect of injecting a trace mineral and vitamin complex during the transition period on reproductive outcomes and serum metabolite and ion concentrations in multiparous Brown Swiss cows. We hypothesized that trace element and vitamin injections at the beginning of the dry period, during the last three weeks of gestation, after parturition and $30 \pm 5$ days postpartum would increase the reproductive parameters. When considering all cows' data, pregnancy rates at first or third services did not differ between treatments. However, the second service pregnancy rate and odds of total pregnancy were greater in the treatment group than in the control. The literature review showed inconsistent results regarding the role of trace mineral and vitamin injections on fertility. Campbell et al. (1999) showed that trace element administration positively impacted fertility by decreasing calving to first oestrus interval. Griffiths et al. (2007) and Pontes et al. (2015) also reported that vitamin administrations increased pregnancy rate in dairy cows. As well as trace element injections increased the success rate of embryo transfer studies (Sales et al. 2011). However, Machado et al. (2013) and Bach et al. (2015) did not find any positive effect of trace element supplementation on fertility. Furthermore, the trace mineral supplementation increased the risk of metritis (Machado et al. 2013). Additionally, Bach et al. (2015) stated that the exact mechanism by which trace elements affect reproduction is unknown. There are 
several theories exist on how the trace element and vitamin affect reproductive parameters. Trace elements and vitamins have a role in enzymatic and metabolic pathways that interact with steroidogenesis, small follicle cell proliferation, and embryo development (Griffiths et al. 2007, Faes et al. 2009). The period from the primordial follicle pool to the selection and ovulation of the follicles is approximately 4-5 months (Webb et al. 2003). The higher total pregnancy rate in the treatment group may have increased the quality of follicle and oocyte developing from the primordial follicle pool by trace element and vitamin applications since the beginning of the dry period, and thus higher pregnancy may be achieved. Besides, trace element supplementation decreases the number of bacteria species in the microbiota of early postpartum uterus. Trace elements and vitamin administrations influence innate and humoral immune systems; thus, uterine health might be protected at the molecular level.

On the other hand, those compounds are assigned on the antioxidant system, thereby the negative effect of reactive oxygen species which produced by immune and somatic cells might be prevented on follicle as well as testis level (Wintergerst et al. 2007, Tafuri et al. 2015). Galvão et al. (2010) detected a greater negative energy balance in cows with endometritis. Bicalho et al. (2014) reported that endometritic cows had lower blood calcium level. These findings coincided with the present study and NEFA concentration was greater, with decreased $\mathrm{Ca}$ concentration in the treatment group at the prepartum period. Numerical differences may be observed due to metabolic inflammation, which resulted from an increase in NEFA concentration at the prepartum period.

Body condition score is a simple method to assess the energy status in dairy cows. Because there is a strong relationship between BCS and energy balance. There is evidence that trace element supplementation does not impact BCS (Sales et al. 2011, Bicalho et al. 2014, Machado et al. 2014). Similarly, in our study, trace element and vitamin administration did not affect the BCS. Colostrogenesis, accelerated foetal growth, hormonal disturbances, parturition and beginning of lactation during the transition period resulted in increased metabolic demands. Furthermore, these physiological changes decreased dry matter intake and resulted in negative energy balance. As a result of negative energy balance, gluconeogenesis and lipomobilization rate alters. This change triggers the severity of negative energy balance (Joksimović Todorović and Davidović 2012). Even so, trace element and vitamin concentration did not affect glucose concentration (Avc1 and Krzil 2013), manganese had a negative role on carbohydrate metabolism (Ömür et al. 2016), thus supplementation might decrease the prepartum glucose concentration. However, the glucose concentration increased after parturition in treated cows and was greater. This result consistent with Nayyar et al. (2003). The possible mechanism of the increase in glucose concentration might be the influence of treatment. Because selenium shows insulin-like activity, it had a role in glycolysis and gluconeogenesis pathways (Stapleton 2000).

The increased concentration of NEFA during the prepartum period $(\geq 0,4 \mathrm{mEq} / \mathrm{L})$ is a risk factor for retained placenta, metritis and ketosis (LeBlanc 2006). González et al. (2011) reported that postpartum NEFA concentration had no relationship with subclinical ketosis, mostly it is related to postpartum lipomobilization. The present study showed that trace element and vitamin treatment might increase the severity of lipomobilization at prepartum period. However, NEFA concentration was in physiological level in both groups at the postpartum period. Notwithstanding, treated cows had higher prepartum NEFA concentration, both groups had similar metabolic and infectious problems. Thus, trace element and vitamin injection during the transition period might suppress the negative effect of prepartum lipomobilization and decrease the incidence of peripartum problems. NEFA is converted to BHB by the liver and used by brain, heart, liver, and mammary glands in ruminants (Drackley and Andersen 2006). Machado et al. (2013) reported that trace element injections during the transition period decreased $\mathrm{BHB}$ concentration. However, in the present study, BHB concentration was not affected by treatment. The possible difference might be the weak correlation between NEFA and BHB (Cavestany et al. 2005).

The role of cholesterol on ruminant energy metabolism unknown exactly. In one theory, increased concentration of cholesterol better for energy balance, on the other hand, Bruss et al. (1997) reported that increased cholesterol results from energy deficiency in dairy cows. Chandra et al. (2018) observed increased cholesterol concentration after trace element and vitamin supplementation, similar to the present study.

Urea concentration directly related to hepatic function and composition of ration (Strang et al. 1998). In comparison with Chandra et al. (2018), the urea concentration was increased after parturition in treated cows. This changes possibly related to prepartum increased NEFA and decreased glucose concentration, resulting in the usage of protein reserves in the body and increased urea concentration. Also, ration composition changes affect the urea concentration, but the same ration is offered to the control and treatment groups. A similar mechanism might be effective for decreased total protein concentration in the prepartum period. We observed an increase in total protein and albumin concentration after parturition in treated cows while it remained similar or showed a decrease in control cows. Hence, similar to Ömür et al. (2016), trace element and vitamin combination had a positive role in protein metabolism.

Liver enzymes activities and hepatic function markers help determine liver status in transition cows (Bertoni and Trevisi 2013). Like Schäfers et al. (2018) AST, GGT, GLDH concentrations were in 
physiological ranges in treatment and control groups. Moreover, increased NEFA concentration negatively affects hepatic function markers, but in the present study, liver enzymes were not affected (within the reference ranges) by greater NEFA concentration. Thus, possibly, trace element and vitamin combination might suppress the negative effect of increased NEFA concentration.

Calcium is an ion that direct relationship with immune parameters and muscle cell functions. It might be a marker for determining immune cell functions during the transition period (Martinez et al. 2012). Decreased calcium concentration increase the cortisol level and chemotactic and bactericidal activities of immune cells are suppressed (Salak-Johnson and McGlone 2007). Also, cytosolic Ca2+ concentration affected by total calcium levels. Cytosolic $\mathrm{Ca} 2+$ has no direct relation with phagocytosis; it has a role at the beginning of the activity (Sayeed 2000). With decreased glucose and increased NEFA, the level of low calcium might be the result of depression of dry matter intake. Adipocytes stimulated by calciumsensitive receptor agonists decrease the basal lipolysis; however, excessive lipolysis decreases the calcium level (Cifuentes et al. 2005). Another role of calcium is in energy metabolism as a seconder messenger. Thus, directly affect the cycle of tricarboxylic acid. The decrease in calcium concentration resulted in alteration in carbohydrate metabolism and tricarboxylic acid cycle, which resulted in severe negative energy balance (Chamberlin et al. 2013). We considered that trace element and vitamin supplementation and calcium and phosphorus injection after parturition might suppress the severity of negative energy balance.

\section{CONCLUSION}

The present study showed that cows injected with trace element and vitamin supplementation at 230 or 260 days of gestation, around parturition and $30 \pm 5$ days postpartum had greater odds of becoming pregnant than control cows. Combined injectable trace elements and vitamins increase the quality of inseminable follicles leading to ovulation in the postpartum period. Also, trace element and vitamin administration positively affect energy, hepatic and ion metabolism. However, the exact mechanism by which trace elements and vitamins affect bovine fertility requires further research.

Explanation: This article was produced from the first author's $\mathrm{PhD}$ dissertation entitled 'Effect of injectable vitamin and trace element administrations during transition period on fertility in Brown Swiss dairy cows'. This work was done under the project entitled 'The effect of injectable trace minerals and vitamins on neutrophil leucocyte activity and fertility in Brown Swiss cows and heifers' supported by the Ankara University Scientific Research Projects Coordination Unit (Project Number:16B0239001), Ankara, Turkey.
Thanks: The authors are grateful to Ufuk Kaya and Pınar Ambarcıoğlu for their kind assistance.

Ethics Committee Information: This study was approved by Ankara University HADYEK number 2015-12-139 in accordance with the "Regulation on the Working Procedures and Principles of Animal Experiments Ethics Committees". In addition, the authors have declared that Research and Publication Ethics are observed. All procedures performed in studies involving animals were in accordance with the ethical standards of the Ankara University Institutional Animal Ethics Committee (2015-12-139).

Conflict of interest: The authors declare that there is no actual, potential or perceived conflict of interest for this article.

\section{REFERENCES}

Avc1 C, Kız1 O. The effects of injectable trace elements on metabolic parameters in transition cow. Kafkas Univ Vet Fak Derg. 2013; 19: 73-78.

Bach, A, Pinto A, Blanch M. Association between chelated trace mineral supplementation and milk yield, reproductive performance, and lameness in dairy cattle. Livest Sci. 2015; 182: 69-75.

Bell AW. Regulation of organic nutrient metabolism during transition from late pregnancy to early lactation. J Anim Sci. 1995; 73: 2804-2819.

Bertoni G, Trevisi E. Use of the liver activity index and other metabolic variables in the assessment of metabolic health in dairy herds. Vet Clin North Am Food Anim Prac. 2013; 29: 413-431.

Bicalho MLS, Lima FS, Ganda EK, Foditsch C, Meira EBS, Machado VS, Bicalho RC. Effect of trace mineral supplementation on selected minerals, energy metabolites, oxidative stress, and immune parameters and its association with uterine diseases in dairy cattle. J Dairy Sci. 2014; 97, 4281-4295.

Bruss ML. Lipids and ketones, In: Clinical Biochemistry of Domestic Animals, Ed; KanekoJ, Harvey JW, Bruss ML, 6th Ed., Academic Press, New York, USA. 1997; pp.86105.

Campbell MH, Miller JK, Schrick FN. Effect of additional cobalt, copper, manganese, and zinc on reproduction and milk yield of lactating dairy cows receiving bovine somatotropin. J Dairy Sci. 1999;82:1019-1025.

Cavestany D, Blanch JE, Kulcsar M, Uriarte G, Chilibroste P, Meikle A, Febel H, Ferraris A, Krall E. Studies of the transition cow under a pasture-based milk production system metabolic profiles. J Vet Med A Physiol Pathol Clin Med. 2005; 52:1-7.

Chamberlin WG, Middleton JR, Spain JN, Johnson GC, Ellersieck MR, Pithua P. Subclinical hypocalcemia, plasma biochemical parameters, lipid metabolism, postpartum disease, and fertility in postparturient dairy cows. J Dairy Sci. 2013; 96:7001-7013.

Chandra G, Aggarwal A, Kumar M, Singh AK. Effect of zinc and vitamin E supplementation on hormones and blood biochemicals in peri-partum Sahiwal cows. J Trace Elem Med Biol. 2018; 50:489-497. 
Cifuentes M, Albala C, Rojas C. Calcium-sensing receptor expression in human adipocytes. Endocrinol. 2005; 146:2176-2179.

Contreras GA, O'Boyle NJ, Herdt TH, Sordillo LM. Lipomobilization in periparturient dairy cows influences the composition of plasma nonesterified fatty acids and leukocyte phospholipid fatty acids. J Dairy Sci. 2010; 93:2508-2516.

Drackley JK, Andersen JB. Splanchnic metabolism of longchain fatty acids in ruminants. In: Ruminant physiology digestion, metabolism and impact of nutrition on gene expression, immunology and stress, Ed; SejrsenK, HvelplundT, Nielsen MO, 1st Ed., Academic Publishers, Wageningen, Holland. 2006; pp. 199-224.

Drackley JK, Dann HM, Douglas N, Guretzky NAJ, Litherland NB, Underwood JP, Loor JJ. Physiological and pathological adaptations in dairy cows that may increase susceptibility to periparturient diseases and disorders. Ital J Anim Sci. 2005; 4:323-344.

Drackley JK, Overton TR, Douglas NG. Adaptationsof glucose and long chain fatty acid metabolism in liver of dairycows during the periparturient period. J Dairy Sci. 2001; 84:100-112.

Faes MR, Caldas-Bussiere MC, Viana KS, Dias BL, Costa FR, Escocard RM. Nitric oxide regulates steroid synthesis by bovine antral granulosa cells in a chemically defined medium. Anim Reprod Sci. 2009; 110(3-4):222236

Ferguson JD, Galligan DT, Thomsen N. Principal descriptors of body condition score in Holstein cows. J Dairy Sci. 1994; 77:2695-2703.

Galvão KN, Flaminio M, Brittin SB, Sper R, Fraga M, Caixeta L, Gilbert RO. Association between uterine disease and indicators of neutrophil and systemic energy status in lactating Holstein cows. J Dairy Sci. 2010; 93(7):2926-2937.

Goff JP. Calcium and magnesium disorders. Vet Clin North Am Food Anim Prac. 2014; 30:359-381.

González FD, Muiño R, Pereira V, Campos R, Benedito JL. Relationship among blood indicators of lipomobilization and hepatic function during early lactation in highyielding dairy cows. J Vet Sci. 2011; 12:251-255.

Griffiths LM, Loeffler SH, Socha MT, Tomlinson DJ, Johnson AB. Effects of supplementing complexed zinc, manganese, copper and cobalt on lactation and reproductive performance of intensively grazed lactating dairy cattle on the South Island of New Zealand. Anim Feed Sci Technol. 2007; 137:69-83.

Hayırlı A, Grummer RR, Nordheim EV, Crump PM. Animal and dietary factors affecting feed intake during the prefresh transition periods in Holsteins. J Dairy Sci. 2002; 85:3430-3443.

Heins BJ, Hansen LB, Seykora AJ. Calving difficulty and stillbirths of pure Holsteins versus crossbreds of Holstein with Normande, Montbeliarde, and Scandinavian Red. J Dairy Sci. 2006; 89:2805-2810.

Hoedemaker H, Prange D, Gundelach Y. Body condition change ante- and postpartum, health and reproductive performance in German Holstein cows. Reprod Dom Anim. 2009; 44:167-173.

Hoedemaker M, Prange D, Zerbe H, Frank J, Daxenberger A, Meyer HHD. Peripartal propylene glycol supplementation and metabolism, animal health, fertility, and production in dairy cows. J Dairy Sci. 2004; 87:21362145.

Joksimović Todorović M, Davidović V. Changes in white blood pictures and some biochemical parameters of dairy cows in peripartum period and early

lactation. Mljekarstvo. 2012; 62(2):151-158.

LeBlanc SJ. Monitoring programs for transition dairy cows, In: Proc 26th World Biuatrics Congress, Nice, France. 2006; pp. 460-472.

Little MW, O'Connell NE, Welsh MD, Mulligan FJ, Ferris CP. Concentrate supplementation of a diet based on medium-quality grass silage for 4 weeks prepartum Effects on cow performance, health, metabolic status, and immune function. J Dairy Sci. 2017; 100:4457-4474.

Machado VS, Bicalho MLS, Pereira RV, Caixeta LS, Knauer WA, Oikonomou G, Bicalho R. C. Effect of an injectable trace mineral supplement containing selenium, copper, zinc, and manganese on the health and production of lactating Holstein cows. Vet J. 2013; 197:451-456.

Machado VS, Oikonomou G, Lima SF, Bicalho MLS, Kacar C, Foditsch C, Bicalho RC. The effect of injectable trace minerals (selenium, copper, zinc, and manganese) on peripheral blood leukocyte activity and serum superoxide dismutase activity of lactating Holstein cows. Vet J. 2014; 200(2):299-304.

Martinez N, Risco CA, Lima FS, Bisinotto RS, Greco LF, Ribeiro ES, Santos JEP. Evaluation of peripartal calcium status, energetic profile, and neutrophil function in dairy cows at low or high risk of developing uterine disease. J Dairy Sci. 2012; 95:7158-7172.

McArt JA, Nydam DV, Oetzel GR. Epidemiology of subclinical ketosis in early lactation dairy cattle. J Dairy Sci, 2012; 95:505-566.

Nayyar S, Gill VK, Malik VS, Roy KS, Singh R. Vitamin E and selenium improve the blood biochemical composition of anoestrus buffalo heifers. Indian J Anim Sci, 2003; 73:654-656.

NRC. Minerals, In: Nutrient Requirements of Dairy Cattle, Ed; Grossblatt N, 7th Ed., National Acadamy of Science, Washington, DC, USA. 2001: pp. 105-162.

Ospina PA, Nydam DV, Stokol T, Overton TR. Association between the proportion of sampled transition cows with increased nonesterified fatty acids and betahydroxybutyrate and disease incidence, pregnancy rate, and milk production at the herd level. J Dairy Sci. 2010; 93:3595-3601.

Ömür A, Kırbaş A, Aksu E, Kandemir F, Dorman E, Kaynar O, Uçar O. Effects of antioxidant vitamins (A, D, E) and trace elements (Cu, Mn, Se, $\mathrm{Zn})$ on some metabolic and reproductive profiles in dairy cows during transition period. Pol J Vet Sci. 2016; 19(4):697-706.

Pogge DJ, Richter EL, Drewnoski ME, Hansen SL. Mineral concentrations of plasma and liver after injection with a trace mineral complex differ among Angus and Simmental cattle. J Anim Sci. 2012; 90:2692-2698.

Politis I. Reevaluation of vitamin E supplementation of dairy cows bio-availability, animal health and milk quality. Animal. 2012; 6:1427-1434.

Pontes GCS, Monteiro PLJ, Prata AB, Guardieiro MM, Pinto DAM, Fernandes GO, Sartori R. Effect of injectable vitamin $\mathrm{E}$ on incidence of retained fetal membranes and reproductive performance of dairy cows. J Dairy Sci. 2015; 98:2437-2449.

Salak-Johnson JL, McGlone JJX. Making sense of apparently conflicting data Stress and immunity in swine and cattle. J Anim Sci. 2015; 85:81-88.

Sales JNS, Pereira RVV, Bicalho RC, Baruselli PS. Effect of injectable copper, selenium, zinc and manganese on the pregnancy rate of crossbred heifers (Bos indicus $\times$ Bos taurus) synchronized for timed embryo transfer. Livest Sci. 2011; 142:59-62. 
Sayeed MM. Exuberant $\mathrm{Ca} 2+$ signaling in neutrophils a cause for concern. Physiology. 2000; 15:130-136.

Scalia D, Lacetera N, Bernabucci U, Demeyere K, Duchateau L, Burvenich C. In vitro effects of nonesterified fatty acids on bovine neutrophils oxidative burst and viability. J Dairy Sci. 2006; 89:147-154.

Schäfers S, Von Soosten D, Meyer U, Drong C, Frahm J, Tröscher A, Dänicke S. Influence of conjugated linoleic acids and vitamin $\mathrm{E}$ on biochemical, hematological, and immunological variables of dairy cows during the transition period. J Dairy Sci. 2018; 101:1585-1600.

Silvia WJ, McGinnis AS, Hatler TB. A comparison of adrenal gland function in lactating dairy cows with or without ovarian follicular cysts. Reprod Biol. 2005; 5:19-29.

Sordillo LM, Aitken SL. Impact of oxidative stress on the health and immune function of dairy cattle. Vet Immunol Immunopathol. 2009; 128:104-109,

Stapleton SR. Selenium an insulin mimetic. Cell Mol Life Sci. 2000; 57(13-14):1874-1879.

Strang BD, Bertics SJ, Grummer RR, Armentano LE. Effect of long-chain fatty acids on triglyceride accumulation, gluconeogenesis, and ureagenesis in bovine hepatocytes. J Dairy Sci. 1998; 81:728-739.

Sundrum A. Metabolic disorders in the transition period indicate that the dairy cows' ability to adapt is overstressed. Animals. 2015; 5(4):978-1020.

Tafuri S, Ciani F, Iorio EL, Esposito L, Cocchia N. Reactive oxygen species (ROS) and male fertility. In: New discoveries in embryology, Ed; WuB, 1st Ed., INTECH, Croatia 2015; 19-33.

Tanaka T, Arai M, Ohtani S, Uemura S, Kuroiwa T, Kim S, Kamomae H. Influence of parity on follicular dynamics and resumption of ovarian cycle in postpartum dairy cows. Anim Reprod Sci. 2008; 108:134-143.

Tilman D, Cassman KG, Matson PA, Naylor R, Polasky S. Agricultural sustainability and intensive production practices. Nature. 2002; 418(6898): 671-677.

Webb R, Nicholas B, Gong JG, Campbell BK, Gutierrez CG, Garverick HA, Armstrong DG. Mechanisms regulating follicular development and selection of the dominant follicle. Reprod Suppl. 2003; 61:71-90.

Williams EJ, Fischer DP, Pheiffer DU, England GCW, Noakes DE, Dobson H, Sheldon IM. Clinical evaluation of postpartum vaginal mucus reflects uterine bacterial infection and the immune response in cattle. Theriogenology. 2005; 63:102-117.

Wintergerst ES, Maggini S, Hornig DH. Contribution of selected vitamins and trace elements to immune function. Ann Nutr Metab. 2007; 51(4):301-323. 